UDC 332.14:338.02

LBC 65.050:65.433

\title{
FINANCIAL ASPECTS OF TOURISM INDUSTRY'S EFFICIENCY IN KARACHAY-CHERKESS REPUBLIC
}

\author{
Rashid A. Kantserov \\ North Caucasian State Humanities and Technological Academy, Cherkessk, Russian Federation
}

\author{
Altynay S. Adzhikova
}

North Caucasian Institute - Branch of Russian Presidential Academy of National Economy and Public Administration, Pyatigorsk, Russian Federation

Nina N. Shkolnikova

North Caucasian State Humanities and Technological Academy, Cherkessk, Russian Federation

\begin{abstract}
The article reveals the relevance of tourism and recreation complex development for the economy of the Karachay-Cherkess Republic. The authors emphasize that tourism in the modern world is one of the most stable and fast growing sectors of the economy. The main types and forms of tourism and recreation in the region are identified with the purpose of increasing revenues from the tourism industry. Special attention is paid to the quantity and quality of recreational resources of the Republic. The article notes that the Karachay-Cherkess Republic has natural resources, mineral sources, scientific and production resources, cultural and historic resources. The authors give a briefdescription of some objects of the Karachay-Cherkess Republic attractive for tourism development, in particular the Nizhny Arkhyz historical and architectural complex, the special astrophysical Observatory of the Russian Academy of Sciences, the Sentinsky historical and architectural complex. The article examines the main characteristics of some investment projects "the Gum-Bashi", "Phia acid sources", "Abaza yard", the implementation of which will contribute to the development of the recreational potential of the region. The work studies the role of the state in regulating the tourism industry development. On the example of the state program, the authors demonstrate the basic target indicators of development of the industry in the near future, including the number of tourists, the number of fee-based tourist services, the number of workers employed in the tourism sector, the number of collective accommodation facilities, etc. In conclusion the authors point out the directions of support and stimulation of tourism business development in the Karachay-Cherkess Republic

Key words: tourism industry, tourism and recreation resources, tourist facilities, investment project, project cost, tourism product, state program.

УДК $332.14: 338.02$

ББК 65.050:65.433

ФИНАНСОВЫЕ АСПЕКТЫ ФОРМИРОВАНИЯ ЭФФЕКТИВНОЙ СИСТЕМЫ ИНДУСТРИИ ТУРИЗМА В КАРАЧАЕВО-ЧЕРКЕССКОЙ РЕСПУБЛИКЕ
\end{abstract}

\section{Рашид Александрович Канцеров}

Северо-Кавказская государственная гуманитарно-технологическая академия, г. Черкесск, Российская Федерация

\section{Алтынай Султахановна Аджикова}

Северо-Кавказский институт - филиал Российской академии народного хозяйства и государственной службы при Президенте Российской Федерации, г. Пятигорск, Российская Федерация

\section{Нина Николаевна Школьникова}

Северо-Кавказская государственная гуманитарно-технологическая академия, г. Черкесск, Российская Федерация 
Аннотация. В статье раскрывается актуальность развития туристско-рекреационного комплекса для экономики отдельно взятого субъекта Российской Федерации - Карачаево-Черкесской Республики. Авторы подчеркивают, что сфера туризма в современном мире является одной из наиболее стабильных и быстрорастущих отраслей экономики. Определены основные виды и формы туризма и рекреации, перспективные для использования в целях наращивания доходов от туристической отрасли в данном регионе. Особое внимание уделяется составу и качеству рекреационных ресурсов КЧР. В статье отмечается, что Карачаево-Черкесская Республика обладает природными ресурсами, минеральными источниками, научно-производственными ресурсами, культурно-историческими ресурсами. Авторы приводят краткую характеристику некоторых объектов Карачаево-Черкесской Республики, привлекательных для развития туризма, в частности НижнеАрхызского историко-архитектурного комплекса, специальной астрофизической обсерватории РАН, Сентинского историко-архитектурного комплекса. В работе исследованы основные характеристики некоторых инвестиционных проектов - «Гум-Баши», «Пхия-Кислые Источники», «Абазинский двор», реализация которых будет способствовать развитию рекреационного потенциала региона. Исследована роль государства в регулировании развития индустрии туризма, отмечены главные факторы, препятствующие развитию туристической отрасли в регионе. На примере государственной программы продемонстрированы основные целевые показатели развития отрасли на ближайшую перспективу, включая численность туристов, объем платных туристических услуг населению, численность работников, занятых в сфере туризма, количество коллективных средств размещения и пр. В заключение представлены направления поддержки и стимулирования развития туристического бизнеса в Карачаево-Черкесской Республике.

Ключевые слова: индустрия туризма, туристско-рекреационные ресурсы, туристические объекты, инвестиционный проект, стоимость проекта, турпродукт, государственная программа.

Развитая туристская индустрия является одним из важнейших факторов социальноэкономического роста регионов. На современном этапе туристическая отрасль является одной из высокодоходных и динамично развивающихся отраслей экономики. Ей присущи особые свойства: ресурсная зависимость, сезонность предоставления услуг, потребность крупных капитальных вложений в развитие инфраструктуры отрасли и пр. Туриндустрию можно рассматривать как сложный межотраслевой комплекс, который включает разноотраслевые предприятия и организации по производству разнообразных товаров и оказанию услуг для туристов. В сфере туризма успешно взаимодействуют предприятия крупного, среднего и малого бизнеса. Активизация туристического бизнеса дает импульс развитию строительства, транспортной инфраструктуры, пищевой промышленности, производству товаров народного потребления. При наличии ресурсных рекреационных возможностей региональный туризм может стать катализатором социально-экономического развития территории.

Карачаево-Черкесская Республика обладает гигантским рекреационным потенциалом, прежде всего, в физико-географическом аспекте. Стратегия развития регионального туризма определяется потребностью формирова- ния собственного качественного туристского продукта и разработки комплекса мероприятий для его продвижения на внутренний и внешний рынки.

Формирование эффективной системы индустрии туризма в Карачаево-Черкесской Республике предполагает:

- создание современного эффективного и конкурентоспособного межотраслевого туристского комплекса;

- создание условий для повышения вклада отрасли туризма в экономику региона с ростом доли более 10 \% в валовом региональном продукте;

- обеспечение диверсификации видов республиканских туристских услуг для увеличения доли регионального турпродукта в туристском комплексе Российской Федерации.

Благодаря разнообразию природных и историко-археологических ресурсов в Карачаево-Черкесской Республике можно развивать самые разнообразные виды и формы туризма и рекреации:

- (медицинский) туризм: климатолечение, бальнеолечение, фитотерапия, гелиотерапия;

- рекреационный туризм, включающий такие программы, как зрелищно-развлекательные, занятия по интересам (охота и рыбная ловля), обучающие, этнические и бытовые (связанные с изучением национальной 
культуры и нетрадиционного быта), оздоровительные;

- спортивный туризм [5, с. 9].

Развитие туризма невозможно без масштабного инвестирования. Сегодня на территории КЧР реализуется более 20 инвестиционных проектов в промышленности, сельском хозяйстве, туризме. Следует отметить, что инвестиции в любую из туристических зон КЧР имеют хорошие перспективы. В горах Карачаево-Черкесской Республики расположены известные центры международного туризма, альпинизма и горнолыжного спорта Домбай, Теберда, Архыз. Площадь горнолыжных зон составляет примерно 200 квадратных километров и может быть сравнима по площади с горнолыжными курортами Французских Альп и Зальцбурга в Австрии. Основные рекреационно-туристические зоны КЧР Домбай, Теберда, Архыз - являются брендовыми для россиян и не требуют существенных затрат на рекламу, они широко известны в России. Для развития современной курортной индустрии в регионе необходимо привлечение инвестиций, которые могут быть вложены в строительство и реконструкцию санаторно-курортных и туристических учреждений, отелей, гостиниц, ресторанов, культурных, научных центров, создание новых видов услуг в банковской системе, в сферу наземного и воздушного транспорта, в развитие телекоммуникаций и связи, в модернизацию развлекательного бизнеса, рекламу.

После продолжительного спада в конце 90-х гг. и последующей стагнации туристско-рекреационная сфера региона в настоящее время имеет стабильную позитивную динамику. Уникальное географическое положение, относитель- но развитая транспортная инфраструктура, богатство природных туристических ресурсов, густая населенность предгорий и гостеприимство местного населения делают КарачаевоЧеркесию одним из наиболее привлекательных регионов для посещения туристами.

В составе туристско-рекреационных ресурсов Карачаево-Черкесии можно назвать следующие:

- лечебно-оздоровительные местности и курорты: курорт Теберда, курорт Домбай, курорт Архыз;

- природные ресурсы: около 200 пещер (10 из них отнесены к памятникам природы), сотни водопадов, более 400 озер, большое количество ботанических и ландшафтных памятников природы;

- минеральные источники: известно более 400, большинство из них обладают целебными свойствами, многие из них расположены в транспортной доступности;

- научно-производственные ресурсы: Специальная астрофизическая обсерватория Российской академии наук - САО РАН;

- культурно-исторические ресурсы: Адиюхское городище, Шоанинский храм, Сентинский храм, Нижне-Архызское городище и пр. $[4$, c. 6$]$.

В числе наиболее популярных достопримечательностей Карачаево-Черкесии, можно назвать объекты, перечисленные в таблице 1.

Ниже приведена краткая характеристика некоторых объектов Карачаево-Черкесской Республики, привлекательных для развития туризма:

- городище VIII-XII вв. и башня Адиюх, расположено в Хабезском районе, на высоком берегу реки Малый Зеленчук;

Таблицุа 1

Перечень основных туристических объектов КЧР

\begin{tabular}{|c|l|c|l|}
\hline 1 & Специальная астрофизическая обсерватория РАН & 9 & Кислые источники Пхия \\
\hline 2 & Древний наскальный образ - Лик Христа & 10 & Дольмены в Зеленчукском районе \\
\hline 3 & $\begin{array}{l}\text { Нижне-Архызский историко-архитектурный и } \\
\text { археологический комплекс }\end{array}$ & 11 & Башня «Адиюх» \\
\hline 4 & Курорт «Домбай» & 12 & Шоанинский храм \\
\hline 5 & Курорт «Архыз» & 13 & Сентинский храм \\
\hline 6 & Курорт «Теберда» & 14 & Кладбище альпинистов в Домбае \\
\hline 7 & $\begin{array}{l}\text { Тебердинский государственный природный био- } \\
\text { сферный заповедник }\end{array}$ & 15 & Софийские водопады \\
\hline 8 & Туристический комплекс «Медовые водопады» & 16 & Озеро Кара-Кель \\
\hline
\end{tabular}

Примечание. Источник: [3]. 
- Музей-памятник «Защитникам перевалов Кавказа» - архитектурный ансамбль, сочетающий мемориальный комплекс с музейной экспозицией;

- Нижне-Архызский историко-архитектурный комплекс, включающий 3 крестовокупольных храма (Северный, Средний и Южный), а также и средневековое городище;

- Специальная астрофизическая обсерватория РАН, являющаяся крупнейшим российским астрономическим центром наземных наблюдений за объектами Вселенной;

- Сентинский историко-архитектурный комплекс, основанный на базе древнего городища, Сентинского храма $\mathrm{X}$ в. и Тебердинского женского Спасо-Преображенского монастыря XIX в.;

- Тебердинский государственный природный биосферный заповедник, являющийся природоохранным, научно-исследовательским и эколого-просветительским учреждением федерального значения;

- Шоанинский историко-архитектурный комплекс, который входит в число историкоархитектурных памятников периода Аланского царства и датируется X в.;

- Хумаринское городище. Памятник, расположенный на берегу реки Кубань, является многослойным, охватывает период с VIIVI вв. до н. э. по VIII-XIV вв. н. э.

Карачаево-Черкесская Республика имеет значительный потенциал для развития самых различных видов туризма. Однако развитие туризма в регионе сдерживается из-за отсутствия достаточного объема инвестиций. Рост активности инвестиционных процессов во многом зависит от создания благоприятных условий для потенциальных инвесторов, в том числе и частных предпринимателей. Поэтому для привлечения инвестиций в развитие курортно-рекреационного комплекса КЧР необходимо разработать комплекс экономических механизмов, способных оказать побудительное воздействие на потенциальных инвесторов.

В Республике продолжается работа по совершенствованию управления туристскорекреационным комплексом. В частности, принят закон Карачаево-Черкесской Республики от 14 мая 2015 г. № 19-Р3 «О некоторых вопросах туристской деятельности в КЧР» (ред. от 01.07.2016 № 38), в котором предусмотрены основные механизмы регулирования развития отрасли. В этом документе указаны принципы, цели, приоритетные направления и методы государственного регулирования туристской деятельности, а также функции Координационного совета по развитию туризма при Правительстве КЧР. Законом предусмотрено ведение мониторинга состояния и использования туристских ресурсов в Карачаево-Черкесской Республике, на основании которого готовится ежегодный Доклад о состоянии развития туризма в КЧР. По его итогам разрабатываются и направляются рекомендации органам государственной власти, местного самоуправления муниципальных образований в Карачаево-Черкесской Республике, общественным организациям и другим заинтересованным лицам [2, с. 16].

В рамках подготовки Стратегии развития внутреннего и въездного туризма в Северо-Кавказском федеральном округе на период до 2035 г. все субъекты федерального округа должны максимально проработать «дорожные карты» с учетом межрегионального взаимодействия в целях дальнейшего наращивания потока российских и иностранных туристов. Полновесная реализация туристического потенциала региона благоприятствует проявлению мультипликативного эффекта туризма, оказывая стимулирующее влияние на межотраслевой хозяйственный комплекс территории.

Инвестиционная политика в сфере туризма в регионах СКФО после утверждения Стратегии развития внутреннего и въездного туризма может быть аналогична работе по подпрограммам Госпрограммы развития округа до 2025 г., то есть регионы будут самостоятельно отбирать наиболее выгодные и привлекательные для них проекты, а также участвовать в их финансировании.

При разработке региональных стратегий развития туризма необходимо также учитывать возможные негативные последствия для местного населения, в числе которых можно назвать рост цен на товары, услуги, землю, недвижимость; ухудшение экологической обстановки и пр. Следует принимать эффективные меры для сохранения экологического равновесия. 
Разнообразие и емкость природного рекреационного потенциала Карачаево-Черкесской Республики привлекает внимание не только российских, но и зарубежных инвесторов. Создание туристско-рекреационных кластеров и субкластеров в Карачаево-Черкесской Республике в ходе реализации инвестиционных проектов будет способствовать стимулированию развития малого предпринимательства, формированию материальной базы туризма, созданию дополнительных рабочих мест в сфере туризма и смежных отраслях.

Активизация инвестиционных процессов является одним из ключевых факторов развития туризма в регионе. Увеличение потока инвестиций позволит обеспечить обновление и создание новых объектов туриндустрии КЧР. Несомненный интерес для формирования и продвижения туристического продукта республики представляют инвестиционные про- екты «Гум-Баши», «Пхия-Кислые Источники», «Абазинский двор» (табл. 2).

Перевал Гум-Баши является красивейшим местом Кавказа. Дорога из Кисловодска в Теберду проходит на высоте 2145 м над уровнем моря, где открывается живописная панорама Главного Кавказского хребта, а также вид на гору Эльбрус. Проект «ГумБаши» предусматривает создание на территории Карачаевского муниципального района близ аула Мара туристско-рекреационного оздоровительного комплекса, способного одновременно принять и разместить со всеми удобствами более 500 человек для продолжительного отдыха, а также туристов, прибывающих на ознакомительные однодневные автобусные экскурсии. В комплекс услуг будут включены такие традиционные для Карачаево-Черкесской Республики виды активного отдыха, как конные и пешие прогулки, катание на лыжах и

Таблица 2

Сведения об инвестиционных проектах КЧР «Гум-Баши», «Пхия-Кислые Источники», «Абазинский двор»

\begin{tabular}{|c|c|c|c|c|c|}
\hline $\begin{array}{c}\text { Полное наимено- } \\
\text { вание инвестици- } \\
\text { онного проекта }\end{array}$ & $\begin{array}{c}\text { Информационная справка } \\
\text { о проекте (описание } \\
\text { и цель проекта) }\end{array}$ & $\begin{array}{c}\text { Место реализации } \\
\text { проекта }\end{array}$ & $\begin{array}{c}\text { Общая } \\
\text { стоимость } \\
\text { проекта, } \\
\text { млн руб. } \\
\end{array}$ & $\begin{array}{c}\text { Количество } \\
\text { создаваемых } \\
\text { рабочих } \\
\text { мест } \\
\end{array}$ & $\begin{array}{l}\text { Объем налого- } \\
\text { вых отчислений }\end{array}$ \\
\hline $\begin{array}{l}\text { Создание тури- } \\
\text { стско-рекреа- } \\
\text { ционного ком- } \\
\text { плекса «Гум- } \\
\text { Баши» }\end{array}$ & $\begin{array}{l}\text { Туристско-рекреационный } \\
\text { оздоровительный комплекс } \\
\text { «Гум-Баши», способный од- } \\
\text { новременно принять и раз- } \\
\text { местить со всеми удобствами } \\
\text { более } 500 \text { человек для мно- } \\
\text { годневного отдыха, а также } \\
\text { туристов, прибывающих на } \\
\text { однодневные автобусные } \\
\text { экскурсии }\end{array}$ & $\begin{array}{l}\text { КЧР, Карачаевский } \\
\text { район, урочище } \\
\text { «Гум-Баши», спра- } \\
\text { ва от } 33 \text { км автодо- } \\
\text { роги Карачаевск - } \\
\text { Кисловодск }\end{array}$ & 900 & $100-160$ & $\begin{array}{l}42 \text { млн руб./год } \\
\text { по плану после } \\
\text { выхода на пол- } \\
\text { ную проектную } \\
\text { мощность }\end{array}$ \\
\hline $\begin{array}{l}\text { Создание всесе- } \\
\text { зонного курорт- } \\
\text { ного комплекса } \\
\text { «Пхия-Кислые } \\
\text { Источники» }\end{array}$ & $\begin{array}{l}\text { Создание всесезонного тури- } \\
\text { стско-рекреационного кла- } \\
\text { стера. } \\
\text { Создание санаторно-курорт- } \\
\text { ной инфраструктуры. } \\
\text { Строительство гостиниц, са- } \\
\text { наториев, пунктов общест- } \\
\text { венного питания в макси- } \\
\text { мальной близости от Санчар- } \\
\text { ских (Пхиинских) источни- } \\
\text { ков минеральной воды }\end{array}$ & $\begin{array}{l}\text { Карачаево-Черкес- } \\
\text { ская Республика, } \\
\text { Урупский муници- } \\
\text { пальный район, } \\
\text { п. Пхия }\end{array}$ & 7900 & 500 & $\begin{array}{l}\text { До } 300 \text { млн руб. } \\
\text { ежегодно в } \\
\text { бюджеты всех } \\
\text { уровней после } \\
\text { выхода на пол- } \\
\text { ную мощность }\end{array}$ \\
\hline $\begin{array}{l}\text { Создание тури- } \\
\text { стско-гостинич- } \\
\text { ного экскурси- } \\
\text { онно-этнографи- } \\
\text { ческого ком- } \\
\text { плекса «Абазин- } \\
\text { ский двор» }\end{array}$ & $\begin{array}{l}\text { Проект предусматривает } \\
\text { создание многофункцио- } \\
\text { нального туристско-гости- } \\
\text { ничного экскурсионно-этно- } \\
\text { графического комплекса } \\
\text { «Абазинский двор» с объек- } \\
\text { тами размещения, питания и } \\
\text { развлечения }\end{array}$ & $\begin{array}{l}\text { Карачаево-Черкес- } \\
\text { ская Республика, } \\
\text { Малокарачаевский } \\
\text { муниципальный } \\
\text { район, п. Красный } \\
\text { Восток }\end{array}$ & 979 & 40 & $\begin{array}{l}30 \text { млн руб. } \\
\text { ежегодно в } \\
\text { бюджеты всех } \\
\text { уровней после } \\
\text { выхода на } \\
\text { полную мощ- } \\
\text { ность }\end{array}$ \\
\hline
\end{tabular}

Примечание. Источник: [3]. 
сноубордах, дельтапланеризм, рыболовные и охотничьи туры. Будут организованы недостаточно развитые в КЧР виды активного отдыха: катание на снегоходах и вездеходах, зорбинг, гонки на квадроциклах и горных велосипедах, культурно-познавательный туризм. Срок реализации проекта составляет 3 года, срок окупаемости - 5 лет. Сметная стоимость проекта - 900 млн руб., его реализация позволит трудоустроить до 200 человек, поступление налогов в бюджетную систему превысит 40 млн руб. в год.

По расчетам, создание всесезонного туристско-рекреационного кластера «ПхияКислые Источники» в Урупском муниципальном районе КЧР позволит привлечь в регион до 100 тыс. туристов в год. Реализация этого масштабного инвестиционного проекта предусматривает создание санаторно-курортной инфраструктуры; строительство гостиниц, санаториев, пунктов общественного питания и пр. в непосредственной близости от Санчарских (Пхиинских) источников минеральной воды. На площади около 200 кв. м выходят на поверхность 17 различных источников минеральной воды с уникальным химическим составом. Следует отметить, что проект имеет особую значимость и включен в программу развития Северо-Кавказского федерального округа. Срок реализации проекта намечен в период с 2021 по 2025 г., при этом срок окупаемости составит 8 лет. Общая его стоимость составляет около 8 млрд руб., а ежегодные поступления налогов будут достигать 300 млн руб. после выхода на полную мощность.

Национальные особенности региона позволит показать создание туристско-гостиничного экскурсионно-этнографического комплекса «Абазинский двор». Данный проект предусматривает строительство в п. Красный Восток Малокарачаевского муниципального района объектов размещения, питания и развлечения в стиле «Абазинского двора» с характерной архитектурой. Для Карачаево-Черкесской Республики использование данного аспекта развития туризма особенно важно, учитывая богатство и яркую индивидуальность национальных традиций и обычаев народов республики. Этим инвестиционным проектом предполагается строительство автомобильной дороги, линии электропередач, систем водоснабжения и канализации и пр. Срок реализации проекта -3 года, срок окупаемости -5 лет.

Кроме того, к перспективным относятся инвестиционные проекты по формированию новых и развитию существующих туристических комплексов: «Теберда-Домбай» в Карачаевском муниципальном районе и Карачаевском городском округе; «Большая Лаба» в Урупском муниципальном районе; «Узун-Кол», «Джилы-су» и «Махар» в Карачаевском муниципальном районе; «Мара» в Карачаевском и УстьДжегутинском муниципальных районах; «Учкекен», «Медовые водопады» в Малокарачаевском муниципальном районе. Пока многие из этих туристических объектов являются невостребованными из-за неразвитости инфраструктуры туристической отрасли, а также несовершенства действующего механизма государственного регулирования туризма.

Министерство экономического развития Карачаево-Черкесской Республики ведет реестр приоритетных инвестиционных проектов и инвестиционных соглашений, а также осуществляет контроль за их реализацией. Для проверки достоверности сведений, получаемых от инвесторов в процессе реализации проектов, и для анализа эффективности предоставления государственной поддержки инвестиционной деятельности раз в полгода проводится выездная проверка объекта с привлечением специалистов профильных ведомств $[1$, c. 32].

В настоящее время в Карачаево-Черкесии реализуется государственная программа «Развитие туризма, курортов и молодежной политики Карачаево-Черкесской Республики на 2016-2020 годы», составной частью которой является подпрограмма 1 «Развитие туризма на 2016-2020 годы». Целями госпрограммы и подпрограммы являются реализация туристического потенциала региона и его развитие.

Госпрограммой предусмотрено решение следующих важных задач:

- сохранение культурного и исторического наследия, обеспечение доступа граждан к культурным ценностям;

- повышение качества и доступности услуг в сфере внутреннего и международного туризма; 
- создание благоприятных условий устойчивого развития сферы культуры и туризма.

К планируемым результатам реализации государственной программы можно отнести:

- перевод отраслей культуры и туризма на инновационный путь развития, превращение культуры и туризма в наиболее развитые и привлекательные сферы общественной деятельности в том числе с использованием информационных технологий;

- разработка и реализация комплекса мероприятий по повышению качества, расширению ассортимента предоставления услуг в сфере туризма;

- создание благоприятных условий для улучшения культурно-досугового обслуживания населения, укрепления материально-технической базы отрасли туризма.

Сведения о составе и значениях целевых показателей подпрограммы 1 «Развитие туризма на 2016-2020 годы» в составе государственной программы «Развитие туризма, курортов и молодежной политики КарачаевоЧеркесской Республики на 2016-2020 годы» приведены в таблице 3.

В частности, с 2015 по 2020 г. в период действия госпрограммы ожидается увеличение внутреннего туристического потока с 867,7 до 1400 тыс. чел., то есть на 61,3 \%. При этом объем платных туристических услуг населению, в том числе за счет увеличения количества средств размещения приезжающих, возрастет более чем на 800 млн руб. и превысит 2 млрд рублей.

В ходе разработки программы развития туризма были выявлены следующие основные факторы, препятствующие росту эффективности туристической отрасли:

1) низкий уровень развития туристской инфраструктуры (недостаточность средств размещения всех видов категорийности и объектов досуга, неудовлетворительное состояние многих туристских объектов, отсутствие качественной придорожной инфраструктуры на автодорогах и др.);

2) отсутствие доступных инвесторам долгосрочных кредитных инструментов с процентными ставками, позволяющими окупать инвестиции в объекты туристско-рекреационного комплекса;

3) низкое качество обслуживания в различных секторах туристской индустрии из-за отсутствия достаточного количества высококвалифицированных профессиональных кадров и пр.

Соответственно выявленным факторам были разработаны и меры по модернизации ту-

Целевые показатели государственной программы «Развитие туризма, курортов и молодежной политики Карачаево-Черкесской Республики на 2016-2020 годы», подпрограмма 1 «Развитие туризма на 2016-2020 годы»

\begin{tabular}{|c|c|c|c|c|c|c|c|c|}
\hline \multirow{2}{*}{$\begin{array}{c}\text { № } \\
\Pi / \Pi\end{array}$} & \multirow[b]{2}{*}{ Наименование целевого показателя } & \multirow{2}{*}{$\begin{array}{l}\text { Единица } \\
\text { измерения }\end{array}$} & \multicolumn{6}{|c|}{ Значения целевых показателей } \\
\hline & & & 2015 & 2016 & 2017 & 2018 & 2019 & 2020 \\
\hline 1 & $\begin{array}{l}\text { Объем платных туристических ус- } \\
\text { луг населению и услуг гостиниц и } \\
\text { аналогичных средств размещения }\end{array}$ & $\begin{array}{l}\text { млн } \\
\text { руб. }\end{array}$ & 1262,5 & 1601,6 & 1793,8 & 1950,0 & 2020,0 & 2125,0 \\
\hline 2 & Внутренний туристический поток & $\begin{array}{l}\text { тыс. } \\
\text { чел. }\end{array}$ & 867,7 & 950 & 1050 & 1107,0 & 1361,0 & 1400,0 \\
\hline 3 & $\begin{array}{l}\text { Численность работников, занятых в } \\
\text { сфере туризма и сопутствующих } \\
\text { отраслях }\end{array}$ & $\begin{array}{l}\text { тыс. } \\
\text { чел. }\end{array}$ & 11,4 & 11,9 & 12,2 & 12,3 & 12,9 & 13,1 \\
\hline 4 & $\begin{array}{l}\text { Инвестиции в сферу туризма в рам- } \\
\text { ках реализации Программы }\end{array}$ & $\begin{array}{l}\text { тыс. } \\
\text { руб. }\end{array}$ & 300,6 & 300431,0 & 225431,0 & 3900,0 & 3900,0 & 3900,0 \\
\hline 5 & $\begin{array}{l}\text { Доля туризма во внутреннем вало- } \\
\text { вом продукте Карачаево-Черкесской } \\
\text { Республики }\end{array}$ & $\%$ & 1,5 & 2,0 & 2,5 & 2,6 & 2,6 & 2,7 \\
\hline 6 & $\begin{array}{l}\text { Въезд иностранных граждан в Ка- } \\
\text { рачаево-Черкесскую Республику }\end{array}$ & $\begin{array}{l}\text { тыс. } \\
\text { чел. }\end{array}$ & 11,2 & 11,8 & 12,5 & 12,5 & 12,8 & 13,2 \\
\hline 7 & $\begin{array}{l}\text { Количество коллективных средств } \\
\text { размещения }\end{array}$ & ед. & 148 & 150 & 156 & 156 & 158 & 160 \\
\hline 8 & $\begin{array}{l}\text { в том числе экономического класса } \\
(\text { категории } 1 *-3 *)\end{array}$ & ед. & 144 & 147 & 153 & 153 & 154 & 156 \\
\hline
\end{tabular}

Примечание. Составлено авторами по: [4, с. 27]. 
ристической отрасли. Реализация Госпрограммы обеспечит устойчивое развитие туристической отрасли в долгосрочной перспективе.

Поставленные задачи предполагается решить за счет следующих конкретных инструментов и мер государственной поддержки:

1) создание внутрирегиональных и межрегиональных туристских кластеров и туристских брендов;

2) создание благоприятного режима для инвестиций в туристскую инфраструктуру;

3) формирование представления о КЧР как о регионе, благоприятном для туризма как для российских, так и для зарубежных граждан;

4) повышение эффективности мер, обеспечивающих безопасность туристов;

5) обеспечение участия КЧР в международных мероприятиях в сфере туризма;

6) формирование единого туристского пространства на территории РФ.

Наиболее актуальные мероприятия по формированию эффективной индустрии туризма в Карачево-Черкесской Республике приведены в таблице 4.
В 2016 г. общая численность туристов, прибывших на Северный Кавказ, составила 3,5 млн чел., что на 13,4 \% больше показателя 2015 года. Так, Ставропольский край посетили почти 1,4 млн туристов (на $6 \%$ больше, чем в 2015 г.), Карачаево-Черкесскую Республику - около 1 млн чел. (рост на $10 \%$ ), Дагестан - более 510 тыс. чел. (плюс $19 \%$ ), Кабардино-Балкарию - 420 тыс. чел. (на 40 \% больше). По расчетам, число приезжающих в Северо-Кавказский регион туристов в ближайшее время должно превысить 5 млн человек. Исходя из того, что большая часть регионов Северного Кавказа имеет общие проблемы в решении задач повышения эффективности использования рекреационных ресурсов, представляется разумным разработать единую концепцию развития индустрии туризма Северо-Кавказского федерального округа на основе формирования межрегиональных инвестиционных проектов.

Эффективное конкурентоспособное развитие туристско-рекреационного комплекса в Карачаево-Черкесской Республике предполагает: формирование и развитие туристско-рек-

\section{Перечень программных мероприятий по развитию туризма в КЧР}

\begin{tabular}{|c|c|}
\hline Наименование мероприятия & Содержание мероприятия \\
\hline Брэндинг наиболее значимых туробъектов & Разработка бренд-буков \\
\hline $\begin{array}{l}\text { Перевод туристско-рекреационного ком- } \\
\text { плекса на современные технологии тури- } \\
\text { стского обслуживания }\end{array}$ & Субсидирование обучения владельцев предприятий туротрасли \\
\hline $\begin{array}{l}\text { Обучение населения предоставлению но- } \\
\text { вых туруслуг }\end{array}$ & $\begin{array}{l}\text { Подготовка и реализация программы дистанциионного обучения } \\
\text { владельцев частных средств размещения и обслуживания в сфере } \\
\text { сельского и этнографического туризма; } \\
\text { подготовка и проведение выездных семинаров «Основы современно- } \\
\text { го турбизнеса» }\end{array}$ \\
\hline $\begin{array}{l}\text { Внедрение единой системы электронных } \\
\text { продаж услуг туристско-рекреационного } \\
\text { комплекса }\end{array}$ & $\begin{array}{l}\text { Разработка и внедрение программного обеспечения автоматизации } \\
\text { продаж услуг туристского комплекса КЧР через веб-интерфейс сайта } \\
\text { Министерства туризма и курортов КЧР }\end{array}$ \\
\hline $\begin{array}{l}\text { Создание и обслуживание современного } \\
\text { комплекса интернет-маркетинга }\end{array}$ & $\begin{array}{l}\text { Обслуживание сайта Министерства туризма и курортов КЧР; } \\
\text { создание специальных интернет-ресурсов; } \\
\text { продвижение комплекса интернет-ресурсов }\end{array}$ \\
\hline Выставки и презентации & $\begin{array}{l}\text { Аренда выставочных площадей; } \\
\text { подготовка, доставка и инсталляция экспозиций; } \\
\text { изготовление сувенирной продукции }\end{array}$ \\
\hline Организация массовых мероприятий & $\begin{array}{l}\text { Подготовка и проведение исторических, этнографических, экологи- } \\
\text { ческих, музыкальных фестивалей и спортивных соревнований }\end{array}$ \\
\hline Информационная продукция & $\begin{array}{l}\text { Производство и трансляция телевизионных фильмов; } \\
\text { выпуск путеводителей и другой книжной продукции; } \\
\text { пдготовка и выпуск рекламно-информационных материалов в элек- } \\
\text { тронной форме }\end{array}$ \\
\hline Прямая реклама (ATL) & $\begin{array}{l}\text { Телевизионная реклама, реклама на радио, реклама в прессе, наруж- } \\
\text { ная реклама }\end{array}$ \\
\hline
\end{tabular}

Примечание. Источник: [4, с. 35]. 
реационного кластера КЧР; увеличение вклада туристской индустрии в экономику региона; продвижение интересов субъектов туристско-рекреационного кластера КЧР в международных организациях; сохранение и рациональное использование туристских ресурсов.

Для управления проектом создания туристической инфраструктуры в Северо-Кавказском федеральном округе, Краснодарском крае и Республике Адыгея в 2010 г. было создано АО «Курорты Северного Кавказа». Так, в сфере горного туризма в рамках госпрограммы по развитию Северного Кавказа в регионе создается туристический кластер, включающий всесезонные комплексы «Архыз» в Карачаево-Черкесии, «Эльбрус» в КБР, «Ведучи» в Чечне, «Армхи» и «Цори» в Ингушетии, а также «Матлас» и Каспийский прибрежный кластер в Дагестане.

Карачаево-Черкесская Республика занимает ключевую позицию по географическому положению в составе туристского кластера Северо-Кавказского федерального округа, Краснодарского края и Республики Адыгея, имеет уникальные природные и культурно-исторические туристские ресурсы. Благодаря этим факторам туризм в КЧР может стать одной из основных отраслей экономики региона.

Целью формирования туристско-рекреационного кластера должно быть не только создание комфортных условий для отдыхающих, но и обеспечение их безопасности, изыскание инновационных приемов в развитии потенциала туризма, привлечение современных прогрессивных технологий для совершенствования и рационального использования турпродуктов. Рост инвестиций и масштабные совместные проекты государства и бизнеса обеспечат расширение спектра услуг в сфере туризма в КЧР, будут способствовать развитию туристической инфраструктуры.

Стратегическими направлениями развития туризма в ближайшей перспективе в КЧР являются:

1. Создание организационно-правовых и экономических условий для стимулирования развития въездного и внутреннего туризма (совершенствование законодательства по регулированию развития туризма; создание системы мониторинга состояния туристских ресурсов Республики; совершен- ствование системы управления туристским комплексом Республики на региональном и муниципальном уровнях; эффективное использование объектов туристской индустрии; создание благоприятного инвестиционного климата в регионе для инвесторов, вкладывающих средства в развитие туристской инфраструктуры).

2. Повышение качества обслуживания в сфере туризма (создание системы непрерывного обучения персонала для подготовки специалистов по туризму; сертификация субъектов туристской инфраструктуры и туристских центров).

3. Маркетинговая политика продвижения и реализации туристского продукта республики (создание информационного поля о республике как о регионе уникальных туристских ресурсов и формирование положительного туристского имиджа КЧР; организация эффективной системы производства и продаж туристского продукта КЧР) [5, с. 51].

\section{СПИСОК ЛИТЕРАТУРЫ}

1. Закон Карачаево-Черкесской Республики от 17.05.2011 № 23-Р3 «О государственном стимулировании инвестиционной деятельности в КарачаевоЧеркесской Республике» : (ред. от 19.06.2017). - Доступ из справ.-правовой системы «КонсультантПлюс».

2. Закон Карачаево-Черкесской Республики от 14.05.2015 № 19-Р3 «О некоторых вопросах туристской деятельности в Карачаево-Черкесской Республики : (в ред. от 01.07.2016 № 38). - Доступ из справ.-правовой системы «КонсультантПлюс».

3. Официальный сайт Министерства туризма, курортов и молодежной политики КЧР. - Электрон. текстовые дан. - Режим доступа: tourismkchr.ru. Загл. с экрана.

4. Постановление Правительства КарачаевоЧеркесской Республики от 31.10.2013 № 364 «Об утверждении государственной программы “Развитие туризма, курортов и молодежной политики Карачаево-Черкесской Республики на 20162020 годы”» : (ред. от 14.03.2017). - Доступ из справ.правовой системы «КонсультантПлюс».

5. Постановление Правительства КарачаевоЧеркесской Республики от 26.08.2014 № 239 «Об утверждении Стратегии социально-экономического развития Карачаево-Черкесской Республики до 2035 года». - Доступ из справ.-правовой системы «КонсультантПлюс». 


\section{REFERENCES}

1. Zakon Karachaevo-Cherkesskoy Respubliki ot 17.05.2011 № 23-RZ «O gosudarstvennom stimulirovanii investitsionnoy deyatelnosti $v$ Karachaevo-Cherkesskoy Respublike»: (red. ot 19.06.2017) [Law of the Karachay-Cherkess Republic of May 17, 2011 no. 23-RL “On State Stimulation of Investment Activity in the Karachay-Cherkess Republic" (amend. of June 19, 2017)]. Access from Reference Legal System "KonsultantPlyus".

2. Zakon Karachaevo-Cherkesskoy Respubliki ot 14.05.2015 № 19-RZ «O nekotorykh voprosakh turistskoy deyatelnosti v Karachaevo-Cherkesskoy Respubliki: (v red. ot 01.07.2016 № 38) [Law of the Karachay-Cherkess Republic of May 14, 2015 no. 19-RL "On Some Issues of Tourism in the Karachay-Cherkess Republic: (amend. of July 1, 2016 no. 38)]. Access from Reference Legal System "KonsultantPlyus".

3. Ofitsialnyy sayt Ministerstva turizma, kurortov i molodezhnoy politiki KChR [Official Website of the Ministry of Tourism, Resorts and Youth Policy of the Karachay-Cherkess Republic]. URL: tourismkchr.ru.
4. Postanovlenie Pravitelstva KarachaevoCherkesskoy Respubliki ot 31.10.2013 № 364 «Ob utverzhdenii gosudarstvennoy programmy "Razvitie turizma, kurortov i molodezhnoy politiki Karachaevo-Cherkesskoy Respubliki na 2016-2020 gody"»: (red. ot 14.03.2017) [Decree of the Government of the Karachay-Cherkess Republic of October 31, 2013 no. 364 "On Approval of the State Program 'Development of Tourism, Resorts and Youth Policy of the Karachay-Cherkess Republic for 2016-2020"' (amend. of March 14, 2017)]. Access from Reference Legal System "KonsultantPlyus".

5. Postanovlenie Pravitelstva KarachaevoCherkesskoy Respubliki ot 26.08.2014 № 239 «Ob utverzhdenii Strategii sotsialno-ekonomicheskogo razvitiya Karachaevo-Cherkesskoy Respubliki do 2035 goda» [Decree of the Government of the Karachay-Cherkess Republic of August 26, 2014 no. 239 "On Approval of the Strategy of Socio-Economic Development of the Karachay-Cherkess Republic till 2035"]. Access from Reference Legal System "KonsultantPlyus".

\section{Information about the Authors}

Rashid A. Kantserov, Candidate of Sciences (Economics), Professor, Department of Finance and Credit, Director of Institute of Economics and Management, North Caucasian State Humanities and TechnologicalAcademy, Stavropolskaya St., 36, 369001 Cherkessk, Russian Federation, kancerovr@mail.ru.

Altynay S. Adzhikova, Candidate of Sciences (Economics), Head of Department of Economics and Antimonopoly Regulation, Deputy Director of North Caucasian Institute -Branch of Russian Presidential Academy of National Economy and Public Administration, Dunaevskogo St., 5, 357502 Pyatigorsk, Russian Federation, altu77@mail.ru.

Nina N. Shkolnikova, Candidate of Sciences (Economics), Associate Professor, Department of Finance and Credit, North Caucasian State Humanities and Technological Academy, Stavropolskaya St., 36, 369001 Cherkessk, Russian Federation, nnshkolnikova@mail.ru.

\section{Информация об авторах}

Рашид Александрович Канцеров, кандидат экономических наук, профессор кафедры финансов и кредита, директор института экономики и управления, Северо-Кавказская государственная гуманитарно-технологическая академия, ул. Ставропольская, 36, 369001 г. Черкесск, Российская Федерация, kancerovr@mail.ru.

Алтынай Султахановна Аджикова, кандидат экономических наук, заведующая кафедрой экономики и антимонопольного регулирования, заместитель директора, Северо-Кавказский институт - филиал Российской академии народного хозяйства и государственной службы при Президенте Российской Федерации, ул. Дунаевского, 5, 357502 г. Пятигорск, Российская Федерация, altu77@mail.ru.

Нина Николаевна Школьникова, кандидат экономических наук, доцент кафедры финансов и кредита, Северо-Кавказская государственная гуманитарно-технологическая академия, ул. Ставропольская, 36, 369001 г. Черкесск, Российская Федерация, nnshkolnikova@mail.ru. 